\title{
Wiktor Weintraub
}

The death on 14 July 1988 of Wiktor Weintraub, the Alfred Jurzykowski Professor Emeritus of Polish Language and Literature at Harvard, has deprived the academic world of a great scholar and teacher. His personal friends and admirers, and he had many of them, will badly miss the visits to the house in Cambridge where Wiktor, with his inseparable pipe in hand, discoursed with wit and erudition on a wide range of subjects.

Wiktor Weintraub was born in 1908 in the little town of Zawiercie, then in Russian Poland. He studied at the Jagiellonian University in Krakow where he obtained his doctorate working with the well-known historian of Polish literature, Ignacy Chrzanowski. While at Krakow, Weintraub developed close ties with another prominent scholar, Stanisław Kot, which he retained for many years to come.

Possibilities of an academic career after receiving the doctorate were slim in prewar Poland, and one usually had to wait for the death or the retirement of a professor. Hence, Weintraub moved in 1934 to Warsaw where he joined the editorial office of the prestigious Wiadomości literackie which provided him with a regular salary. Then, he was able to marry his cousin, Anna Tennenbaum, whom he had known since childhood. In 1937, he went to France on a fellowship where he stayed for the next two years, exploring the country and its culture in depth. The outbreak of World War II changed the course of his life as it did for most Poles. Unable to cross into Romania when the Polish resistance was collapsing, he found himself in Russian-occupied Lwow and subsequently, together with his wife, was "resettled" by the Soviet authorities near the Ural Mountains.

The Sikorski-Maisky accord of 1941, which established diplomatic relations between the USSR and the Polish government in London, provided for "amnesty" to Poles deported to Russia and allowed the creation of a Polish army there; it made the Weintraubs free again. What is more, the first Polish ambassador was none other than Wiktor's old mentor, Stanisław Kot, who promptly appointed him to his staff. In the summer of 1942, the Weintraubs left Russia, with many other Poles. Their road led through Iran to what was then Palestine. Kot offered Weintraub the editorship of a bimonthly $W$ Drodze destined for the Polish army and civilian émigrés. Among his collaborators was another old friend, the prominent poet, Władysław Broniewski.

In 1945, Weintraub went to London where he worked in the Polish ministry of information until the end of the war, continuing at the same time scholarly pursuits in the British Museum. The first postwar years were for him, as for many others, years of transition: some lecturing at London University, some didactic work at Polish teachers' courses, some writing for Wiadomości polskie, a revised version of the prewar periodical now published in London. The year 1950 marked a big change. In an effort to develop Slavic studies at Harvard, Michael Karpovich proposed, at the advice of Aleksander Lednicki, that Weintraub come as a visiting lecturer to Cambridge. The Weintraubs left Europe and settled in America.

Weintraub's forty-odd years at Harvard belonged undoubtedly to the most fruitful and rewarding in his life. True, he was not spared personal tragedy when in 1967 his wife, a faithful companion and a strong personality, died of cancer. He remarried seven years later. His second wife, Maria Ewelina Żółtowska, a historian of literature, had been Weintraub's informal advisee while completing her Ph.D. at Yale.

In 1954, Weintraub was named associate professor of Slavic languages and literatures at Harvard and, five years later, a full professor. In 1971, the Alfred Jurzykowski Foundation decided to endow a chair in Polish language and literature at Harvard: Wiktor Weintraub was the natural candidate for this chair. It represented his academic apogee.

Wiktor Weintraub's list of publications comprises more than 460 items: books, articles, reviews, introductions, edited works. He was the author of seven books, five of them in Polish and two in English: Styl Jana Kochanowskiego (Krakow, 1932); The Poetry of Adam Mickiewicz (The Hague, 1954); Literature as Prophecy: Scholarship and Martinist Poetics in Mickiewicz's Slavic Review 48, no. 2 (Summer 1989) 
Parisian Lectures (The Hague, 1959); Profecja i profesura: Mickiewicz, Michelet i Quinet (Warsaw, 1975); Rzecz Czarnoleska (Krakow, 1977), Od Reja do Boya (Warsaw, 1977); Poeta i prorok: rzecz o profetyźmie Mickiewicza (Warsaw, 1982). He liked the last book best.

The titles reflect the wide range of Weintraub's knowledge, which encompassed virtually all of Polish literature, and his particular fascination with Kochanowski and Mickiewicz, more specifically the religiosity of the former and the mysticism of the latter. They also show that in the last thirteen years, Weintraub published increasingly in Poland. In fact, two of his works are still in press there: an anthology of Andrzej Morsztyn and the second volume of Rzecz Czarnoleska. One can hope that they will be published soon.

Having spent most of his life abroad and being truly a leading member of the international community of scholars, Wiktor Weintraub retained intimate ties with Poland. The ceremony of reconfirming his doctorate after fifty years at the Jagiellonian University was a tribute paid to him by Polish scholars, admirers, and friends. Shortly before his death, he was named a member of the Polish Academy of Science in Warsaw. His attachment to Harvard and to the Polish chair was gratified by the choice of his successor: Stanisław Barańczak, whom he held in high esteem.

To me and to all those who were Wiktor's close friends, Cambridge will never be the same without him. We mourn his departure and feel his loss. But let me take comfort in a Latin saying - and Wiktor Weintraub continued to read Latin even during his dark hours of illness-non omnis moriar.

Piotr Wandycz Yale University

\section{Robert H. McNeal, 1930-1988}

Robert Hatch McNeal died on 2 June 1988 as a result of injuries sustained in an automobile accident in Medford Lees, N.J. In a career cut short at the age of fifty-eight, McNeal had earned an international reputation as a historian of the late Russian Empire and the Soviet Union.

A 1952 graduate of Yale University, where he was awarded Honors with Exceptional Distinction, the William Andrew White Prize in History, and membership in Phi Beta Kappa, McNeal received a certificate from the Russian Institute at Columbia University in 1954 and a doctorate in history from Columbia in 1958. He taught at Princeton University from 1954 to 1958, at the University of Alberta from 1958 to 1967, at McMaster University from 1962 to 1964 , and at the University of Toronto from 1964 to 1969 . From 1969 until his death he was a professor at the University of Massachusetts at Amherst, where he served as chairman of the history department from 1971 to 1975 . Those of us who had the honor of working with him at any of those institutions will remember him not only for his learning and scholarship but also for his unusual modesty, his unimpeachable integrity, and the exceptional clarity of his mind.

To the wider scholarly world McNeal was known primarily through his many publications on Russian and Soviet history. He edited nine works dealing with the Russian Revolution, Stalin, the Communist party leadership, and other topics, and he wrote and published more than 100 articles and reviews in scholarly journals, symposia, and reference works. He was the author of four books on Russian and Soviet history: The Bolshevik Tradition; Bride of the Revolution, a biography of Nadezhda Krupskaia; Tsar and Cossack 1855-1914; and Stalin: Man and Ruler. The last two of those books were published almost simultaneously in the month preceding his death.

Robert McNeal's sudden death at the age of fifty-eight has deprived the profession of a major scholar and the world of an excellent man. The shock and sense of loss felt by his family and close friends is shared by his colleagues and admirers throughout the profession. 
Arthur P. Mendel, 1927-1988

Arthur P. Mendel, professor of history at the University of Michigan, died on 28 February 1988 after a courageous bout with cancer. Born on 17 July 1927 in Chicago, Arthur was a graduate of Roosevelt College in Chicago and did his graduate work at Harvard, where he received his doctorate in Russian history in 1955. He taught at Roosevelt College and New York University before coming to Michigan in 1962.

Arthur's major work was in Russian intellectual history, a subject he studied and taught with great passion. Generations of Michigan students heard him discuss in his lectures and seminars the celebrated questions of the Russian intelligentsia: "What is Justice?" "Who is to Blame?" "What is to be Done?" Arthur shared with the figures he studied the belief that these questions must concern all responsible thinking men and women, that the task of the scholar and teacher is to draw lessons from the past and present that can define and shape one's life, politics, and social environment. His choice of Russian intellectual history as a field of specialization reflected his sense of what it meant to lead a meaningful and morally responsible life. He believed passionately in freedom and equally strongly opposed those philosophies and historical interpretations that suggest the power of vast impersonal forces over the fates of men and peoples. The history of nineteenth and twentieth century Russia provided him with abundant material to examine and discuss these issues and to explore their reflection in concrete historical situations. Similarly, the world and campus he lived in provided frequent opportunities to present and contest his views and to elaborate his ethical ideals. This he did in earnest good humor, even in the throes of his illness. Few of his colleagues and students avoided these engagements during his twenty-five years at Michigan. All will remember them, and him, with appreciation and respect.

Arthur's major scholarly contributions reflected his deep convictions. Dilemmas of Progress in Tsarist Russia focused on the debate between legal Marxists and legal populists but elaborated at the same time a theory of peaceful social development that its author deemed applicable to India and other developing social orders. Michael Bakunin: Roots of Apocalypse attempted to situate radical political strivings in psychological conditions and to identify the destructive qualities of revolutionary movements and radical change in the personalities and characters of their practitioners. Both books thus reflected Arthur's deep conviction in the power of men and women to shape their destinies, and his equally strong sense of an individual's moral responsibility for social and political actions. More recently, his work turned to the history of utopian and millennarian thought in western civilization. He worked on that project until his final days and left a completed manuscript of the first volume.

Arthur Mendel leaves a rich and valued legacy in his writings, teaching, and personal relationships. His friends and colleagues greatly admired his courage of conviction and will remember his intelligence, warmth and spirit.

Roman SzPorlun and WiLliam G. RosenberG University of Michigan 